\title{
THEORETICAL AND PRACTICAL CONSIDERATIONS \\ REGARDING ABUSIVE CLAUSES IN THE CREDIT CONTRACTS, REGARDED AS ADHESION CONTRACTS
}

\author{
Diana Gorun ${ }^{1}$ \\ Mirela Niculae ${ }^{2}$ \\ Beatrice-Tanta Strat ${ }^{3}$
}

DOI: https://doi.org/10.31410/LIMEN.2019.81

\begin{abstract}
Credit agreements are regarded as adhesion contracts, containing clauses to which the customer is obliged to accept, which can easily be defined as abusive. Because of their unpredicted and onerous effects, it was legally established the unpredictability in the adhesion contracts, which justified the intervention of the courts of instances to review or to adapt the contract according to the exceptional circumstances' changes.
\end{abstract}

Keywords: Unpredictability, Effects, Legislation.

\section{INTRODUCTION. PRELIMINARY ISSUES CONCERNING THE LIMITATION OF COMPULSORY CONTRACT FORCE. THE CIRCUMSTANCE IN CREDIT AGREEMENTS. CONTEXT OF THE NECESSITY OF OCCURRENCE OF LAW NO. 77/2016. CASE LAW AND RELEVANT DOCTRINE}

$\mathrm{T}$ he Romanian legislator, taking into account the evolution of the economic-social situation at the level of the Romanian society and the way in which credit agreements between financial institutions - banking and consumers have been conducted/executed, provided by article 1271 of the new Civil Code an exception to the principle of binding force of the contract. In this category can be included the credit agreements. Under that latter point, it should be noted that, on the role of the courts, many cases have been judged to establish unfair clauses in credit agreements. Of course, we are referring to the adhesion contracts, the unfair terms of which have been found to be $80 \%$ of the courts in the light of legal provisions on consumer protection.

Unfair terms have been established by the courts by a relevant case-law relating to consumer protection.

The historical context was underlined in all judgments handed down by the Romanian courts, by the emergence of the unpredictability in the adhesion contracts, which justified the court's intervention to revise/adapt/terminate the contract in the light of the exceptional changes in the circumstances.

For example, the civil Decision No. 2886 of $5^{\text {th }}$ of September 2017, delivered by the Bucharest Court of Instance - Civil Section VI, in the case no. 13675/300/2016. It is highlighted the historical course of the foreign currency as an exceptional circumstance affecting the performance of the contract in such a way that it has become burdensome for consumers, banks, customers.

\footnotetext{
1 School of Law - Romanian-American University, Bd. Expozitiei no. 1B, sector 1, Bucharest, Romania

2 Faculty of Finance, Banking and Accounting - Christian University Dimitrie Cantemir, Splaiul Unirii no. 176, sector 4, Bucharest, Romania

3 Highest Court of Justice, Bucharest, Romania
} 
Decision on the currency risk clause, in the meaning of ,The accelerated increase in the value of the Swiss franc in relation to the national currency, as well as the expenditure generated by the currency exchange mechanism in lei in Swiss francs and Swiss francs in Lei, the lack of Swiss francs from foreign exchange offices for a long time, the differences between the course of the bank and the foreign exchange offices, namely the course set by BNR, the differences between the sales and purchase rates led to the continuous increase in the cost of contracts, producing a major imbalance of the reciprocal benefits of the parties, to the detriment of the borrows, with the effect of obtaining benefits by the borrowing bank, without consideration from it. The bank stipulated in the contract concluded with the complainant, their obligation to bear exclusively foreign exchange differences, without limiting in any way the scope of that obligation, so that in the situation of doubling the value of the Swiss franc in relation to the national currency the credit agreements concluded between the parties acquire a random character, which leads to a breach of the criterion of equivalence of benefits. The currency risk clause provided solely to consumers distorts the binding legal report by excessively hinting the consumer's situation and at the same time conferring a manifestly disproportionate economic advantage on the bank, which gains unfair gain to the detriment of consumers, contrary to the principles of fairness and good faith, which must govern contractual relations. The Financier, in his professional capacity as a banking system, with a vast portfolio of loans in Swiss francs, both directly in Romania and through the parent bank in Hungary, he met or had to know the studies and specialist reports from the period 2005-2007, prior to granting the loan, made by specialists of the Swiss National Bank - SNB (a. Ranaldo, P. Soderlind, Safe Haven Currencies, SNB Working Paper, 14 September 2007, P. 2; Quarterly report of the Swiss National Bank on the 3/2007 quarter of September 2007, pp. 32-33) and specialists of the National Bank of Romania (Florian Neagu, Angela Margărit, risks to financial stability in Romania generated by the population sector, BNR, study notebooks, August 2005, p. 10; The Financial Stability Report for the year 2006 by B.N.R. in the year 2007, p. 33), which showed that the Swiss franc is a currency with the highest properties of refuge, recording significant assessments during the crisis episodes, 20 in number, from 19932006, and that the risks of exchange rates are fully transferred to uncoated debtors, consumers who do not earn income in Swiss francs. The National Bank of Romania has warned all banks over time (see, to this effect, the retrospective study of B.N.R. in February 2015 entitled Credit Analysis in Swiss francs, p. 29) about the risks of lending, especially in exotic currencies such as the Swiss franc, the currency of a country with which Romania has no very extensive economic ratios. The quotation of this currency (CHF) is made in Romania through the euro, not directly, B.N.R. with no objectives or levers related to the quotation of this coin to the lion. ,

In most cases, banks did not notify the customer of the risk of CHF hyper-valorisation, a predictable phenomenon for the financial experts operating within them, given that CHF is an unstable currency and at the time Conclusion of the Contract - 2007 - 2008-This was at a historical minimum.

By the emergence of this phenomenon, the effects of the legal act came to be other than those which the parties understood to establish, which prompted with necessity the revision of the effects of the contract under the theory of unpredictability, which with the entry into Force of the new Civil code benefits from a general regulatory regulation constituting a legislative transposition of the solutions outlined in practice.

In this situation, the courts in most of the case have appreciated that it is necessary to revise the effects of the contract by stabilising the currency exchange rate and the denomination of the 
payment, given that the change in economic conditions has been unpredictable, with consumers having no specialised knowledge in the financial-banking field allowing them to anticipate a manifest devaluation of the Leu versus CHF. In the same context, it was held that the revision/ adaptation/termination of the effects of the contract corresponds to the agreement of the parties' will, since the CHF hyper-valorisation hijacks the contract from the purpose for which it was concluded whose execution no longer corresponds to the parties' concordant will.

The context presented set up this legal operation of the revision/correction/termination of unfair terms in credit agreements with a view to ensuring the parties under the right imposed on a fair trial, the prompt rescue of the contract being. Thus, it follows that the ,intervention of the court' in such disputes is impetuous necessary in establishing the contractual balance with the correlation of the principle of good faith and fairness. These aspects were stated by the courts vested in the judgment of the actions initiated under Law No. 77/2016, for example, Decision No. 1143 of 13th of December 2017 delivered by the Dolj County Court of Instance - Civil Section. In other cases, without listing them, the courts have summarised to examine only the conditions of admissibility laid down in article 4 of the law.

The courts have extensively motivated the phenomenon of foreign currency in the context of the crisis - economic in the case of finding unfair terms in credit agreements, for example, Decision No. 723 of 12th of December 2017 pronounced by the Buzău County Court of Instance - Civil, administrative and fiscal Section II, Decision No. 2886 of 5th of September 2017 delivered by the Bucharest Court of Instance - Civil Section VI, decision No. 799 of 11th of December 2017 delivered by the Dolj County Court of Instance - Civil Section II, etc.

In addition to those shown above, it is necessary to mention some arguments in the explanatory memorandum to the drafting of the payment law, namely:

„Restoring the contractual balance means that, in the situation of a „contract crisis”, the parties share the risk. In the context of the enforcement procedure, the good, which has come to a much lower value than the original value, will only partially cover the claim, and the debtor who does not hold another good pursuable, obviously, will not be able to pay the remaining uncovered credit difference. The creditor, who would receive in payment the good executed, could mark lost with Celerity and at a lower cost. Therefore, a solutum saves both the debtor's situation (except for unlimited liability, receiving the chance of a new beginning) and the cash-flow-of the Creditor (which will no longer have to constitute provisions and incur legal costs). The debtor will thus share the risk of declining property value with the creditor. ,

Basically, the purpose of the law is a fair solution for both the debtor and the creditor in the context of restoring the contractual balance in the situation of an economic crisis of the contract, by dividing the risk of the contract.

Thus, the legislature provided for in the new Civil Code circumstanced in article 1271, as an exception to the binding effect of the contracts, established on the basis of the pacta sunt servanda principle.

We will no longer analyse the pacta sunt servanda principle, considering the fact that this theme has formed the subject of many debates, the theme of numerous articles, and the jurisprudence is rich and complex. 
Therefore, where there is an event/phenomenon not envisaged by the Contracting Parties at the time of the conclusion of the contract, which significantly affects the contractual balance, so that it becomes very burked for one of the parties, we are in the hypothesis of the unpredictable or hardship; this clause is known in the doctrine under two forms, namely hardship, in English and clause d'imprevision, which originates from the French language. The concept of hardship is a creation of the Anglo-Saxon practice, its use by the parties integrating itself into the dominant tendency to ensure the stability of foreign trade contracts, by promoting legal mechanisms capable of adapting them to the dynamic market conjuncture.

In support of the theory of the unpredictability were invoked as arguments of the rebus sic standibus clause, latin expression used to name the clause that whenever unpredictable events of a kind change the contractual conditions, the existing situation will be maintained at the time of the conclusion of the Convention.

\section{DECISION NO. 623/2016 OF THE CONSTITUTIONAL COURT AND ITS IMPACT OVER THE JUDGMENT OF THE CASES BASED ON THE PROVISIONS OF LAW NO. 77/2016}

Constitutional Court, by Decision No. 623 of $25^{\text {th }}$ of October 2016, published in the Official Gazette of Romania, part I, No. 53 of $18^{\text {th }}$ of January 2017, found that the phrase "as well as the devaluation of immovable property " in art. 11 first sentence of Law No. 77/2016 is unconstitutional and the provisions of art. 11 thesis first reported to art. 3 second thesis, art. 4, 7 and 8 of the Law No. 77/2016 are constitutional in so far as the court verifies the conditions relating to the existence of the circumstance.

As a result, in addition, the judicial practice of court courts now finds the existence of an unpredictability in the cases of finding abusive clauses in credit agreements, contrary to what is envisaged in the interpretation of the Constitutional Court.

Article 11 of the Law on Payment provides as follows: ,"In order to balance the risks arising from the credit agreement, as well as the devaluation of immovable property, this law applies both to credit agreements which are in progress at the time of its entry into force and to contracts concluded after that date."

In other words, the provisions of article 11 concerning the retroactive application of the law, i.e. contracts in progress, are considered to be constitutional, except for the phrase ,as well as the devaluation of immovable property", which has to be eliminated.

For example, in the file No. 2195/215/2016, the Dolj County Court of Instance - Civil Division II, pronounced the decision No. 965 of $7^{\text {th }}$ of November 2017 gave the debtors a profit, stipulating that:" debtors shall notify the Bank of the extinguishing of debts and not the transfer of ownership at a later date, according to articles 7 and 8 of the law and as the Court observes the requirements of the unpredictability, the court retains that the notification made by the corresponds to the meaning of Law no. 77/2016 and tends to lead to the execution, completion of the contract in this special form governed by the legislature by law no. 77/2016, the liabilities of the contract being extinguished". The conclusion of the Translative property contract, respectively from the date of the final judgment, according to the provisions of art. 8 or, where applicable, of art. 9, any debtor's debt to the creditor will be extinguished, the latter unable to claim additional 
sums of money. The provisions of this article shall also benefit from the co-debtor or the other who has guaranteed the obligation of the principal debtor.

This judgment is lawful and thorough, given precisely in accordance with the provisions of Law No. 77/2016 since the Court of Justice had envisaged the fluctuation of the currency in which the credit agreement was concluded but also that, examined another objective element of the unpredictability, namely the devaluation of the value of the apartment brought as collateral for the execution of the credit agreement, is a criterion which in conjunction with the principle of fairness, as part of the unpredictable theory as set up under the old Civil code regime, leads to the generation of imbalance of benefits resulting from the contract of Credit, all the more so as the credit agreement was concluded for the purchase of a dwelling property.

So the Court concludes that "the law of payment shall also apply where, at the time of the occurrence of the normative act, the immovable property has already been executed in the enforcement proceedings and the creditor continues to execute as a result of the flow not fully covered, as is the case in the present case. As long as art. 8 para. 5 enshrines the right of the debtor to be enforced to request the Court to determine the termination of liabilities in the contract, without distinguishing the form of enforced enforcement which continues against the debtor, the creditor's objection to the debtor's notification of the provisions of the Law no. 77/2016 cannot be accepted exclusively for the inexistence of the immovable property in the debtors' patrimony, while they seek to extinguish the remaining debts after the award Foreclosure, Enforcement continues for the difference resulting from the performance of the guarantee. "

In the file no. 23385/215/2016, the Dolj County Court of Instance - Civil Division II has given the debtors a profit, by rejecting the call made by the bank, in the recitals of the decision, among other things, they analysed alongside the evolution of the currency rate, the debtor's financial situation, noting from the probate administered that it is unable to pay the flow due to a significant reduction in revenues. However, as the court of First Instance has analysed the fulfilment of the conditions of the unpredictability by reference to all the circumstances and circumstances of the case, it cannot be held that the court has issued an unlawful and non-legislative sentence.

In this case, the first court examined the circumstance in the light of the decision of the Constitutional Court No. 623/2016. As regards the Analysis of the Fulfilment of the Conditions of the unpredictable, the court found their meeting and, in a subsectional manner, the unfounded nature of the creditor's appeal, having regard to the following: The credit agreement was concluded on 08.07.2008, when the euro value was 3.6102 lei, while, at the time of the wording of the notification, 21.07.2016, the euro value was 4.5411 lei. The statistical data in question are public and are considering the BNR course (and can be accessed on the website www.bnro.ro).

The Court appreciated that an increase in the course of the national currency-foreign currency in which credit was granted, between the date of conclusion of the credit agreement and the date of the wording of the notification, such as the one in the case, exceeds the limits of resonance and passes within the sphere of excessive oncoming, being in the realm of an over-added risk. However, a regular, objective and reasonable consumer of a prudent and diligent man has not assumed a currency fluctuation such as that in the case. The variation in the foreign currency in which the credit was granted-national currency is an external circumstance, independent of the will of the parties which could not reasonably be foreseen at the time of the conclusion of the credit agreement. At the same time, it did not result in any probatory evidence from which 
the consumer debtors assumed a fluctuation exceeding the limits of resonance, passing within the sphere of excessive oncoming. Moreover, the contract did not expressly specify that the consumer debtor assumes the currency risk irrespective of the currency fluctuations which may arise during the performance of the contract between that foreign currency and the national currency. The materialization of the currency risk characteristic of the unpredictable question only at the time of a significant, exceptional overhaul of the limits of variation of the foreseeable course at the time of the conclusion of the contract, either as a sudden effect of a currency shock or as a cumulative effect of a continuous depreciation, and provided that this overhaul would transform the obligation to repay the loan in an excessively onerous way for the debtor.

Such a currency fluctuation, capable of transforming the obligation to repay the loan in an excessively onerous debtor for the borrower, existed in the present case.

Therefore, it was obvious that the debtors were unable to pay off the rates, arriving in the situation of being executed on the property of the mortgage Guardhouse, the building on which a mortgage of rank II was awarded.

It has also been pointed out that the incidence of the principle of monetary nominalism in foreign currency credit agreements does not constitute a barrier to the application of the mechanism of the unpredictability, if the conditions of its incidence are met, a matter retained by the Constitutional Court Decision No. 62/2017.

The specifics of foreign currency credit agreements imply that the materialisation of the currency risk does not affect the intrinsic value of the foreign currency in which the credit is denominated, but the amount of the financial effort to be allocated to the debtor for procurement of resources necessary for reimbursement.

Therefore, the materialisation of the currency risk comes into question at the time of exceeding the limits of the foreseeable course fluctuations at the time of conclusion of the contract, irrespective of whether such overtake is the sudden effect of a currency shock or the cumulative effect of continuous depreciation. The fluctuation of the exchange rate must not be irreversible, but must have a correspondent in serious damage to the consumer's obligation, and in this case, there is such an effect.

\section{CONCLUSION}

In resolving the justified cases - and not only but also those which have as their object the finding of unfair terms in credit agreements - the courts are obliged to consider the Constitutional Court Decision no. 623/2016, namely the fulfilment of the conditions of the unpredictability as follows:

- under the binding force of the previous Civil Code, both the doctrine and the judicial practice acknowledged the possibility of applying the theory of unpredictability where an exceptional and outward event of the will of the parties which could not reasonably be foreseen by them at the time of the conclusion of the contract would render the debtor's obligation excessively onerous. Under the Civil Code regime of 1864, the theory of unpredictability was based on the provisions of art. 970 stipulations: „Conventions must be executed in good faith. They oblige not only to what is expressly in themselves, but to all the consequences, what equity, habit or law gives the obligation to its nature. „So, even 
if it was not enshrined in Terminis, from a normative point of view, the circumstance resulted from the very regulation of the relative principle of contracts, which is justified by the elements of good faith and fairness that characterizes the execution of contracts. The conditions for the application of the unpredictable were made in the case-law and largely taken over in the current Civil Code, in a roughly identical form. (art. 1271);

- the theory of the unpredictability, based on the two principles (the mandatory power of law/force that the contract has for the Contracting Parties, on the one hand, and good faith in its execution, on the other hand), attenuates the binding nature of the contract, in so far as, during the period of its execution, an unpredictable situation arises, but none of the contracting Parties abdicate from its obligations under the good-faith performance of the contract. Therefore, fairness, along with good faith, provides a foundation of the unpredictable, starting from the relationship between them. 